\title{
Shelf life enhancement of low calorie and fiber-enriched Sandes $h$ by modified atmosphere packaging
}

\author{
Himanshu Kumar Rai, Dinesh Chandra Rai, Arvind and Shikha Pandhi
}

Received: 27 June 2020 / Accepted: 01 November 2020 / Published online: 28 February 2021

(c) Indian Dairy Association (India) 2021

\begin{abstract}
Sandesh is the most popular chhana-based sweet delicacy of the eastern part of India, especially West Bengal, India. Sandesh is a heat-acid coagulated product that is rich in high quality animal protein, fat, minerals, and vitamins. The present research was conducted to study the effect of three different combinations of gases i.e. $98 \% \mathrm{CO}_{2}, 98 \% \mathrm{~N}_{2}$ and $50 \% \mathrm{~N}_{2}$ : $50 \% \mathrm{CO}_{2}$ on the shelflife of low calorie and fiber-enriched sandesh samples. The samples packed under air were kept as control. The samples were stored in a BOD incubator at 25 and $37^{\circ} \mathrm{C}$ and analysed for microbial, textural and sensorial changes at an interval of 7 days up to 28 days. The samples packed with air showed significantly higher textural and sensorial changes and microbial spoilage as compared to the other three combinations. The results showed that samples packed with $50 \% \mathrm{~N}_{2}: 50 \% \mathrm{CO}_{2}$ combination had better shelf stability as compared to the samples packed under air, $98 \% \mathrm{~N}_{2}$ and $98 \% \mathrm{CO}_{2}$.
\end{abstract}

Keywords: Sandesh, Sensory attributes, Shelf life, Textural properties

\section{Introduction}

Milk and milk-based products have been an important source of nourishment in our daily life (Kumar and Singh, 2017).India is the largest producer of milk in the world with an annual production

Department of Dairy Science and Food Technology, Institute of Agricultural Sciences, Banaras Hindu University, Varanasi- 221 005, India

Himanshu Kumar Rai $(\bowtie)$

Department of Dairy Science and Food Technology, Institute of Agricultural Sciences, Banaras Hindu University, Varanasi- 221 005, India Email: raihimanshuias@gmail.com; Mobile: +919598232301 of around 155.5 million tonnes (NDDB, 2017). About 50-55\% of the product is converted to traditional Indian dairy products and forms an important part of the cultural heritage of India (Bandopadhyay and Khamrui, 2007). Advancement of technology and incorporation of novel ingredients to restructure traditional dairy products has been the current trend in the market which is majorly leaning towards the development of low calorie and more shelf-stable products (Gawande et al. 2012). Sandesh is a popular traditional dairy product prepared by acid or heat coagulation of milk and mainly admired in the eastern part of India, especially in West Bengal (Saha et al. 2018). It is famous for its palatability, aroma and nutritional value attributed by the presence of good quality proteins, fat, vitamins, minerals etc. It is prepared by the constant mixing of channa with sugar over medium heat (Bandyopadhyay et al. 2008). Cow milk is preferably used for the preparation of channa as it gives smooth texture with uniform grains which are mainly desired for preparation of sandesh (Husain and David, 2018). Limited shelf-life of these products due to their susceptibility to undergo deterioration during storage makes them unfit for consumption (Londhe et al. 2012). Innovations in packaging systems such as vacuum packaging, modified atmosphere packaging have provided an excellent solution by retaining the freshness of perishable as well as nonperishable foods for a comparatively longer time (Chowdhury et al. 2017).

Modified atmosphere packaging (MAP) has come up as an efficient approach to enhance the shelf-life of perishable products without the addition of any chemical additive (Floros and Matsos, 2005). It involves altering the composition of the product surroundings within the food package to protect the product from various microbial and oxidative changes during storage that is triggered by the presence of oxygen in the product surrounding (Jha et al. 2015). Therefore, the presence of a low concentration of residual oxygen in the product surrounding within the packaging system is the key approach utilized in the modified atmosphere packaging of foods for shelf life extension (Sandhya, 2010). Several types of research have been conducted to study the effect of modified atmosphere packaging on the preservation of lal peda ( Londe et al. 2012), paneer (Thippeswamy et al. 2011) and brown peda (Jha et al. 2015) which demonstrated modified atmosphere packaging as a promising technique to extend the 
shelf-life of traditional dairy products. In view of above-mentioned prospect, the present work was undertaken to study the effect of modified atmosphere packaging on the shelf life of low calorie and fiber-enriched sandesh based on sensorial, microbial and textural parameters.

\section{Materials and Methods}

The present work was carried out in the laboratory of the Department of Dairy Science and Food Technology, Banaras Hindu University, Varanasi, India. Low calorie and fiber-enriched sandesh was manufactured using milk standardized to $3 \%$ fat and $8.5 \%$ SNF. The milk was procured from the Dairy Farm, Banaras Hindu University, Varanasi, India. Stevia and sorbitol used for the preparation of low calorie and fiber-enriched sandesh were procured from the local market of Varanasi, India and online sources. The level of sorbitol, oat flour, and stevia optimized using response surface methodology based on sensory scores were $4 \%, 15 \%$ and $0.25 \%$ respectively. The detailed manufacturing process of low calorie and fiber-enriched sandesh was represented with the help of a flow diagram (Figure 1).

\section{Packaging and storage of low calorie and fiber-enriched sandesh}

Three different combinations of gases i.e. $98 \% \mathrm{CO}_{2}, 98 \% \mathrm{~N}_{2}$ and $50 \% \mathrm{~N}_{2}: 50 \% \mathrm{CO}_{2}$ were used to pack the sandesh samples. The samples packed under air were kept as control. The samples were stored in a BOD incubator at 25 and $37^{\circ} \mathrm{C}$ at $60 \%$ relative humidity and analyzed for microbial and textural changes at an interval of 7 days up to 28 days. Tray of dimension $18 \times 12.5 \mathrm{~cm}^{2}$ (Containing 6 pieces of low calorie and fiber enriched sandesh) manufactured by Elixir Technologies was used for packaging.

\section{Microbial analysis}

All the samples were subjected to total plate count (TPC), yeast and mold count (YMC) and coliform count. One gram of sample was properly mixed with distilled water. $1 \mathrm{ml}$ of resultant homogenate was added to $9 \mathrm{ml}$ of sterile saline water in a test tube and diluted serially to obtain a series of dilutions up to 10 \{ $\mathrm{w} .1 \mathrm{ml}$ or $0.5 \mathrm{ml}$ of the appropriate dilutions from each tube was aseptically pipette out and plated on to different selective and differential media using pour plate technique. The TPC was determined on plate count agar (PCA) and incubated at $37^{\circ} \mathrm{C}$ for 24-48 hours. For mold and yeast detection, sample was spread on potato dextrose agar (PDA) and incubation was done at $25^{\circ} \mathrm{C}$ for 24-48 hours. Coliforms in the samples were estimated by plating on violet red bile agar (VRBA) before being incubated at $37^{\circ} \mathrm{C}$ for $24-48$ hours (Kumbhar et al. 2009). The number of microbial counts was calculated using the following formula:

$$
\begin{aligned}
& \text { Colony-forming units }(\mathrm{CFU}) / \mathrm{ml}= \\
& \qquad \begin{array}{l}
\text { factor } \\
\text { Weight of aliquot taken }(\mathrm{ml})
\end{array}
\end{aligned}
$$

\section{Texture profile analysis (TPA)}

TPA on samples was performed by using the Texture Analyser (TA.XT plus texture profile analyzer, Stable Micro Systems, UK) to characterize the hardness, adhesiveness, springiness, cohesiveness and gumminess of the optimized sandesh. During the textural analysis, samples of optimized sandesh were cut into $1.5 \mathrm{~cm}^{3}$ size pieces and their temperature was maintained at $25^{\circ} \mathrm{C}$.

\section{Sensory analysis}

The sensory quality of low calorie and fiber-enriched 'sandesh' samples were judged by a panel of 10 semi-trained judges from the Department of Dairy Science and Food Technology. The samples were evaluated for sensory attributes viz., color and appearance, flavor, sweetness, body and texture and overall acceptability based on a 9-point hedonic scale (Amerine et al. 1965).

\section{Statistical Analysis}

All experiments were performed in triplicate. Data is expressed as mean value. The means were compared using Duncan's multiple range test (DMRT) at $\mathrm{P}<0.05$. One-way analysis of variance (ANOVA) was performed as described by Snedecor and Cochran (1989), to test the significance of data in each trial and parameter.

\section{Results and Discussion}

Microbial changes of low calorie and fiber-enriched sandesh samples were analyzed at an interval of 7 days of storage. Total plate count and yeast and mold count on day zero was 4.87 and $2.85 \log _{10} \mathrm{CFU} / \mathrm{g}$, respectively. Coliforms were not detected in the samples during the entire study period. Microbial loads in different gas combinations are shown in Table 1. In the samples stored under air at 25 and $37^{\circ} \mathrm{C}$, microbial activity reached the critical limits after 14 days of storage. Hence, the samples were discontinued after 14 days of storage. In other samples stored with $98 \% \mathrm{~N}_{2}, 98 \% \mathrm{CO}_{2}$ and $50 \% \mathrm{~N}_{2}: 50 \% \mathrm{CO}_{2}$ at 25 and $37^{\circ} \mathrm{C}$, there was an increase in the TPC and YMC, within 28 days and no coliforms were detected. Critical limits were reached at 28 days of storage. All the samples stored under MAP displayed a continuous increase in the total plate count and yeast and mold populations during 28 days of storage period. However, if compared with the samples containing $98 \% \mathrm{~N}_{2}$ and $98 \% \mathrm{CO}_{2}$, the growth of the microbial populations was lower in the case of $50 \%$ $\mathrm{N}_{2}: 50 \% \mathrm{CO}_{2}$ atmosphere package during the 28 day storage period. The samples containing $98 \%$ nitrogen displayed delayed microbial growth as nitrogen is an inert gas that does not support microbial growth. However, as observed, samples with $98 \% \mathrm{CO}_{2}$ displayed increased inhibition of microbial growth when compared to samples containing $98 \% \mathrm{~N}_{2}$, probably due to the bacteriostatic effect of $\mathrm{CO}_{2}$, as mentioned in several earlier reports (Daniels et al. 1985; Banks and Annis, 1990; Davis, 1998; Devlieghere and Debevere, 2000). Smith et al. (1986) reported 


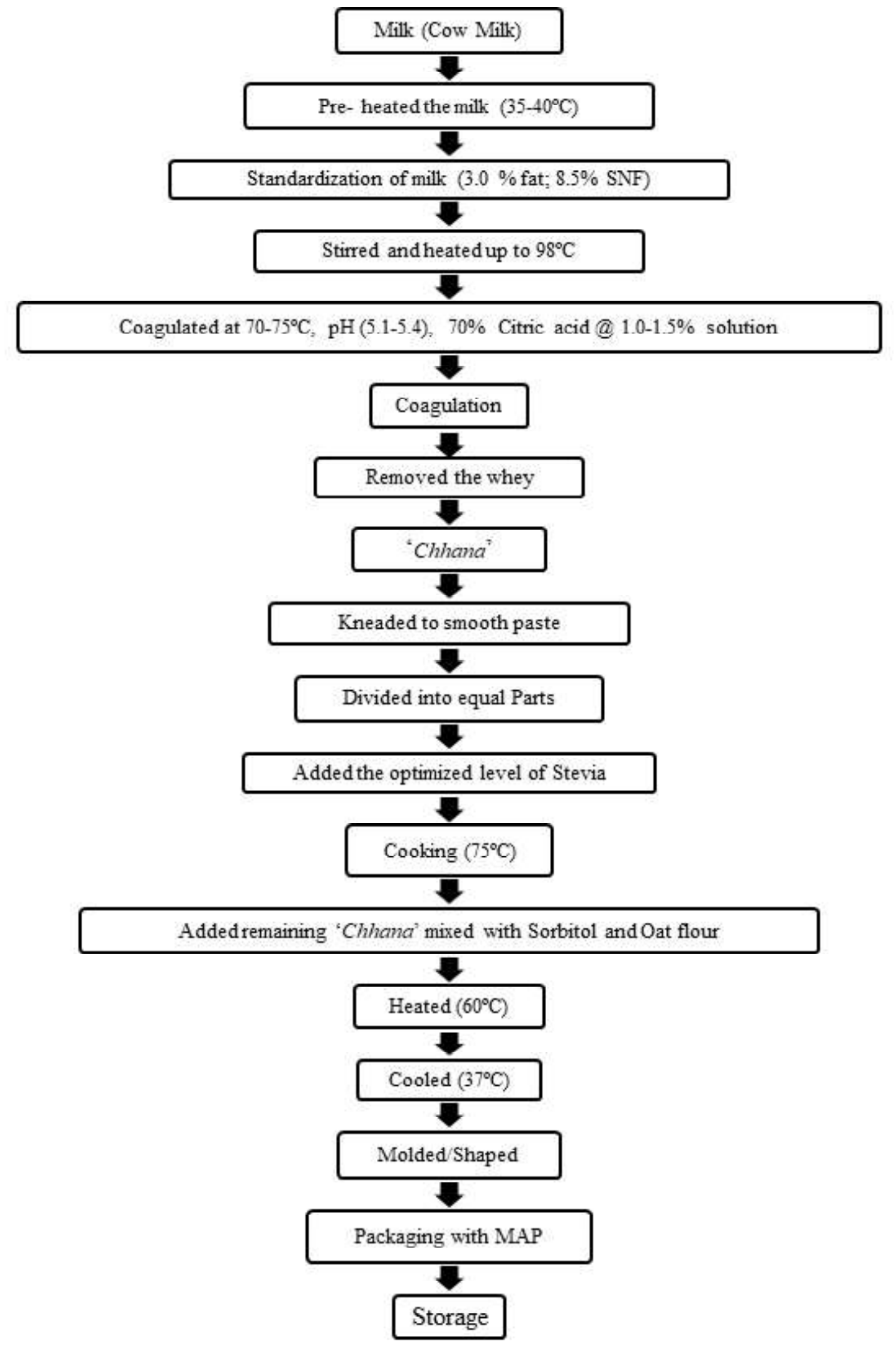

Fig. 1 Flow diagram of low calorie and fiber enriched sandesh preparation 
that the gas packaged $\left(40 \% \mathrm{~N}_{2}: 60 \% \mathrm{CO}_{2}\right)$ crusty rolls with the headspace $\mathrm{O}_{2}$ concentration never increased beyond $0.05 \%$ and the rolls remained mold-free even after 60 days.

\section{Changes in Textural properties}

The textural properties of any product are important criteria to determine the acceptability of the product. Table 2 depicts the textural changes in sandesh during storage. There was a continuous increase in the hardness of the sandesh samples with an increase in the storage period for the control samples and the MAP samples. The hardness varied significantly with variation in the gas composition and the storage temperature. Table 2 shows that the hardness of the sandesh samples increased significantly $(\mathrm{P}<0.05)$ with an increase in the temperature, the hardness of the samples packed under air increased to a greater extent than those packed under the MAP conditions. The hardness of any product is directly related to its moisture content. It can be observed from Table 2, that the samples packed under $50 \% \mathrm{~N}_{2}: 50 \% \mathrm{CO}_{2}$ showed the minimum changes in hardness, which could be attributed to its better moisture retention under the MAP conditions.

The cohesiveness of a product is the ratio of the area under the second bite curve before reversal compression to under the first bite curve. It is the measure of the extent to which the structure of the product was disrupted during the first compression. The average cohesiveness of the samples remained constant throughout the storage period with no significant variation. Also, change in temperature did not show any significant effect on the cohesiveness during 14 days of storage but varied significantly after 14 days with temperature variation. The cohesiveness increased initially during the storage period, but later it decreased marginally. These observations are similar to those reported by Londhe et al. (2012) in brown peda and Jha et al. (2015) in lal peda. Loss in moisture content could be the reason for the loss of cohesiveness with the progression of the storage period. Gupta et al. (1990) also reported similar findings in khoa with an increase in total solids.

The springiness of a food refers to its ability to return to its original form after compression. It is the height that the product recovers between the first and the second compression. The springiness for sandesh samples did not vary significantly $(\mathrm{P}>0.05)$ for up to 07 days of storage at all the temperatures in the control and the MAP samples. However, the springiness increased with further increase in storage period and varied significantly $(\mathrm{P}<0.05)$ with variation in the storage temperature and gas composition. Jha et al. (2015) reported similar observations in lal peda samples stored under MAP conditions.

The adhesiveness of a product is related to its sensory stickiness. Table 2 shows that the average adhesiveness of the sandesh samples decreased gradually, with increasing the storage period. The average adhesiveness of the samples had a significant change with an increase in temperature from 25 to $37^{\circ} \mathrm{C}$. This decline in the adhesiveness could be due to the decrease in free moisture during the storage. A similar trend in adhesiveness was observed in the lal peda samples by Jha et al. (2015).

Gumminess is the product of hardness and cohesiveness. It can be seen from Table 2, that the average gumminess of sandesh was significantly $(\mathrm{P}<0.05)$ affected by variation in the temperature.

Table 1 Microbial changes in low calorie and fiber enriched sandesh during storage packaged under air and under MAP

\begin{tabular}{|c|c|c|c|c|c|}
\hline \multirow[t]{2}{*}{$\overline{\text { Days }}$} & \multirow[t]{2}{*}{ Atmosphere } & \multicolumn{2}{|c|}{ Total plate count $\left(\log _{10} \mathrm{cfu} / \mathrm{g}\right)$} & \multicolumn{2}{|c|}{ Yeast and mold count $\left(\log _{10} \mathrm{cfu} / \mathrm{g}\right)$} \\
\hline & & $25^{\circ} \mathrm{C}$ & $37^{\circ} \mathrm{C}$ & $25^{\circ} \mathrm{C}$ & $37^{\circ} \mathrm{C}$ \\
\hline 0 & & $4.87 \pm 0.004$ & $4.87 \pm 0.04$ & $2.85 \pm 0.02$ & $2.85 \pm 0.02$ \\
\hline \multirow{4}{*}{07} & Control & $5.43 \pm 0.04^{\mathrm{aA}}$ & $5.58 \pm 0.03^{\mathrm{Aa}}$ & $2.94 \pm 0.03^{\mathrm{aA}}$ & $3.12 \pm 0.02^{\mathrm{aA}}$ \\
\hline & $98 \% \mathrm{CO}_{2}$ & $4.94 \pm 0.02^{\mathrm{aA}}$ & $4.99 \pm 0.02^{\mathrm{Ab}}$ & $2.87 \pm 0.01^{\mathrm{aA}}$ & $3.03 \pm 0.02^{\mathrm{aA}}$ \\
\hline & $98 \% \mathrm{~N}_{2}$ & $4.97 \pm 0.03^{\mathrm{aA}}$ & $5.08 \pm 0.04^{\mathrm{Ab}}$ & $2.88 \pm 0.03^{\mathrm{aA}}$ & $3.08 \pm 0.03^{\mathrm{aA}}$ \\
\hline & $50: 50:: \mathrm{CO}_{2}: \mathrm{N}_{2}$ & $4.90 . \pm 0.01^{\mathrm{aA}}$ & $4.95 \pm 0.05^{\mathrm{Ab}}$ & $2.86 \pm 0.02^{\mathrm{aA}}$ & $2.93 \pm 0.01^{\mathrm{aA}}$ \\
\hline \multirow[t]{4}{*}{14} & Control & $6.69 \pm 0.02^{\mathrm{aA}}$ & $6.82 \pm 0.01^{\mathrm{Aa}}$ & $3.42 \pm 0.02^{\mathrm{aA}}$ & $3.55 \pm 0.03^{\mathrm{aA}}$ \\
\hline & $98 \% \mathrm{CO}_{2}$ & $5.01 \pm 0.03^{\mathrm{bA}}$ & $5.13 \pm 0.04^{\mathrm{Ab}}$ & $2.95 \pm 0.02^{\mathrm{bA}}$ & $3.19 \pm 0.02^{\mathrm{bA}}$ \\
\hline & $98 \% \mathrm{~N}_{2}$ & $5.13 \pm 0.01^{\mathrm{bA}}$ & $5.48 \pm 0.03^{\mathrm{Ab}}$ & $3.01 \pm 0.02^{\mathrm{bA}}$ & $3.26 \pm 0.04^{\mathrm{bA}}$ \\
\hline & $50: 50:: \mathrm{CO}_{2}: \mathrm{N}_{2}$ & $4.96 \pm 0.02^{\mathrm{bA}}$ & $5.16 \pm 0.03^{\mathrm{Ab}}$ & $2.89 \pm 0.01^{\mathrm{bA}}$ & $3.01 \pm 0.02^{\mathrm{bA}}$ \\
\hline \multirow[t]{3}{*}{21} & $98 \% \mathrm{CO}_{2}$ & $5.38 \pm 0.01^{\mathrm{aA}}$ & $5.68 \pm 0.03^{\mathrm{Ba}}$ & $3.09 \pm 0.03^{\mathrm{aA}}$ & $3.19 \pm 0.02^{\mathrm{aA}}$ \\
\hline & $98 \% \mathrm{~N}_{2}$ & $5.43 \pm 0.03^{\mathrm{aA}}$ & $5.81 \pm 0.03^{\mathrm{Ba}}$ & $3.15 \pm 0.01^{\mathrm{aA}}$ & $3.26 \pm 0.04^{\mathrm{aA}}$ \\
\hline & $50: 50:: \stackrel{\mathrm{CO}_{2}}{2}: \mathrm{N}_{2}$ & $5.10 \pm 0.03^{\mathrm{aA}}$ & $5.39 \pm 0.02^{\mathrm{Bb}}$ & $2.94 \pm 0.03^{\mathrm{aA}}$ & $3.01 \pm 0.02^{\mathrm{aA}}$ \\
\hline \multirow[t]{3}{*}{28} & $98 \% \mathrm{CO}_{2}$ & $5.89 \pm 0.03^{\mathrm{aA}}$ & $6.19 \pm 0.02^{\mathrm{Aa}}$ & $3.18 \pm 0.03^{\mathrm{aA}}$ & $3.28 \pm 0.03^{\mathrm{aA}}$ \\
\hline & $98 \% \mathrm{~N}_{2}$ & $6.01 \pm 0.04^{\mathrm{aA}}$ & $6.21 \pm 0.03^{\mathrm{Aa}}$ & $3.32 \pm 0.02^{\mathrm{aA}}$ & $3.45 \pm 0.02^{\mathrm{bA}}$ \\
\hline & $50: 50:: \mathrm{CO}_{2}: \mathrm{N}_{2}$ & $5.28 \pm 0.02^{\mathrm{bA}}$ & $5.78 \pm 0.02^{\mathrm{Ba}}$ & $3.12 \pm 0.03^{\mathrm{aA}}$ & $3.19 \pm 0.02^{\mathrm{aA}}$ \\
\hline
\end{tabular}

Values are mean \pm standard deviation, $\mathrm{n}=3$

* Values with different small superscripts in columns are significantly different $(\mathrm{p}<0.05)$ within each interval

* Values with different capital superscripts in rows are significantly different $(p<0.05)$ within each interval 

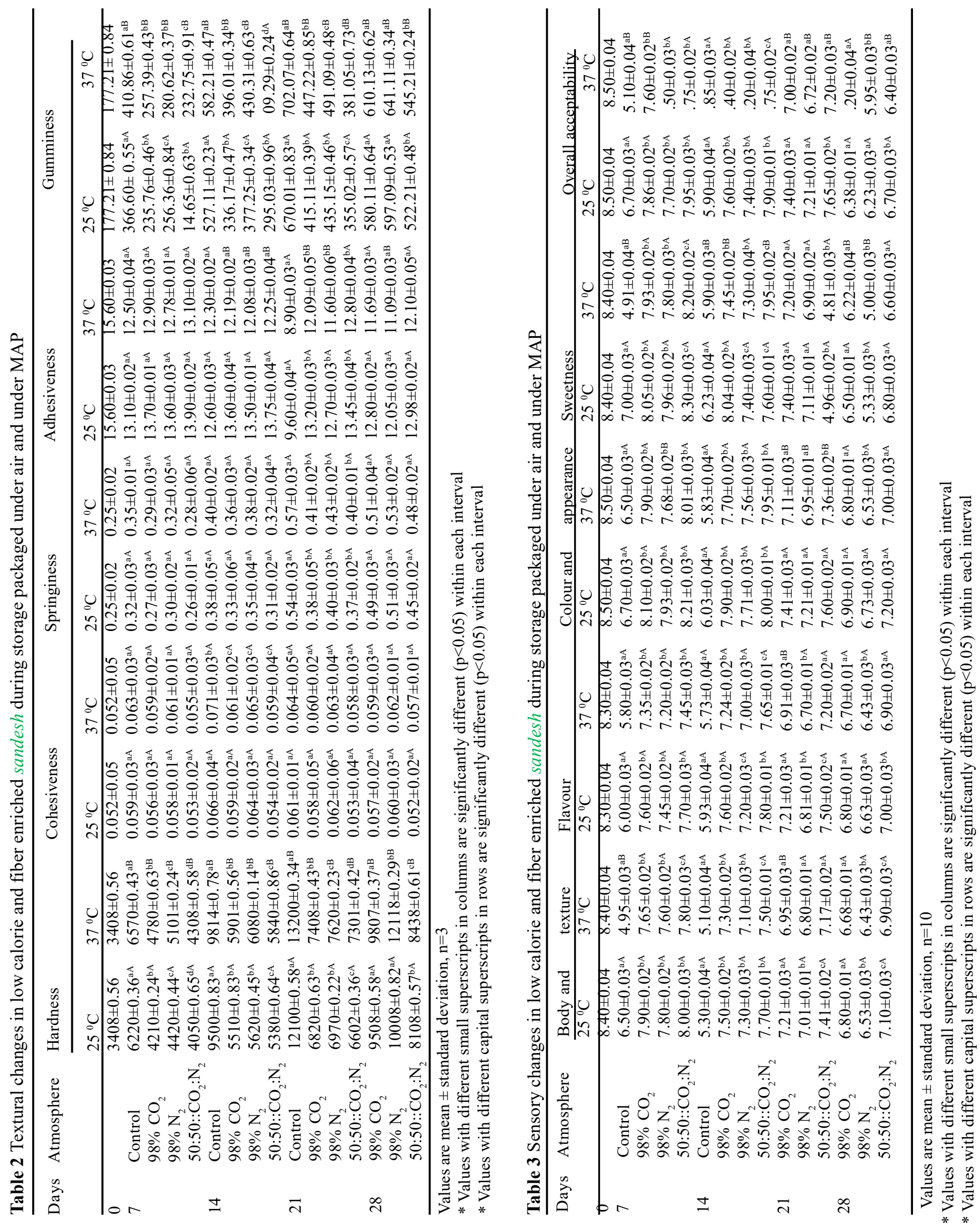
It was lower in samples stored at $25^{\circ} \mathrm{C}$, which gradually increased with an increase in the storage temperature to $37^{\circ} \mathrm{C}$. The variation in gas composition had a significant $(\mathrm{P}<0.05)$ effect on the gumminess of sandesh sample during the storage period.

\section{Changes in sensory attributes}

The average score for all sensory attributes decreased significantly $(\mathrm{P}<0.05)$ with the storage period. The control samples were found to be unacceptable after 14 days, hence discarded from the further sensory evaluation. The samples packed under $50 \% \mathrm{~N}_{2}: 50 \% \mathrm{CO}_{2}$, scored the maximum among all the samples for all the sensory properties at their respective storage temperatures and storage periods. The sensory scores for body and texture, flavor, color and appearance, sweetness and overall acceptability varied significantly $(\mathrm{P}<0.05)$ among MAP samples during storage at every temperature (Table 3 ). An increase in the storage temperature had a negative effect on the sensory score of the product and this can be deduced from the fact that the samples stored at $37^{\circ} \mathrm{C}$ showed lower sensory score as compared to samples stored at $25^{\circ} \mathrm{C}$. The samples stored at $25^{\circ} \mathrm{C}$ packed under $50 \% \mathrm{~N}_{2}: 50 \% \mathrm{CO}_{2}$ showed the highest sensory characteristics of the samples.

\section{Conclusions}

An attempt was made to evaluate the shelf life of sandesh stored under air and MAP with variation in gas composition viz. $98 \% \mathrm{~N}_{2}$, $98 \% \mathrm{CO}_{2}$ and $50 \% \mathrm{~N}_{2}: 50 \% \mathrm{CO}_{2}$ during two different storage temperatures $\left(25\right.$ and $\left.37^{\circ} \mathrm{C}\right)$. The samples stored under air had a short shelf life as compared to samples stored under MAP. Therefore, the MAP could be considered as a better option for storage of sandesh. The samples packed under $50 \% \mathrm{~N}_{2}: 50 \% \mathrm{CO}_{2}$ was optimally effective in preserving the microbial and textural properties of sandesh. During the storage period, the textural property of optimized products also varies significantly. The hardness of the product increases significantly as the storage time increases and was more prominent at $37^{\circ} \mathrm{C}$ due to greater loss of moisture as compared to the storage temperature of $25^{\circ} \mathrm{C}$. Gumminess and springiness also increase over the storage period and the adhesiveness of the experimental product decreases during the storage at both storage temperature. This study could prove to be helpful in the preservation of other traditional dairy products using MAP.

\section{References}

Amerine MA, Pangborn RM, Roessler EB (1965) Principles of sensory evaluation of foods. Academic Press, London

Bandyopadhyay M, Chakraborty R, Raychaudhuri U (2008) Antioxidant activity of natural plant sources in dairy dessert (Sandesh) under thermal treatment. LWT-Food Sci Technol 41: 816- 825

Bandyopadhyay P, Khamrui K (2007) Technological Advancement on Traditional Indian Desiccated and Heat Acid Coagulated Dairy Products. Bulletin-International Dairy Federation 415:1-7
Banks HJ, Annis PC (1990) Comparative advantages of high $\mathrm{CO}_{2}$ and low $\mathrm{O}_{2}$ types of controlled atmospheres for grain storage. In: Calderon M, Barkai-Golan R (eds) Food preservation by modified atmospheres. CRC Press Inc, Boca Raton, pp 93-122

Chowdhury T, Chattopadhyay SK, Saha NC (2017) Modified atmosphere packaging (MAP) and the effect of chemical preservative to enhance shelf life of khoa (heat desiccated milk product). J Packag Technol Res 1: 25-31

Daniels JA, Krishnamurthi R, Rizvi SSH (1985) A review of effect of carbon dioxide on microbial growth and food quality. J Food Prot 48:532-537

Davis HK (1998) Fish and shellfish. In: Blakistone BA (ed) Principles and applications of modified atmosphere packaging of foods, 2ndedn. Blackie Academic \& Professional, London, pp 194-239

Devlieghere F, Debevere J (2000) Influence of dissolved carbon dioxide on the growth of spoilage bacteria. LWT-Food Sci Technol 33:531537

Floros JD, Matsos KI (2005) Introduction to modified atmosphere packaging. In: Han JH (ed) Innovations in food packaging. Elsevier Ltd, London, pp159-172

Gawande H, Shendurse A, Dhotre A (2012) Low calorie traditional milk sweets in India: A review. Indian Food Ind 31: 43-51

Gupta SK, Patil GR, Patel AA, Garg FC, Rajorhia GS (1990) Instron texture profile parameters of khoa as influenced by composition. J Food Sci Technol 27:209-213

Husain SA, David J (2018) Studies on sensory attributes of herbal sandesh by incorporation of ashwagandha (Withaniasomnifera) and tulsi (Ocimum sanctum) at room temperature. J Pharmacogn Phytochem7: 2567-2571

Jha A, Kumar A, Jain P, Gautam AK, Rasane P (2015) Effect of modified atmosphere packaging on the shelf life of lal Peda. J Food Sci Technol 52: 1068-1074

Kumar A, Singh SS (2017) Preparation and quality assessment of Chhanapodo prepared by using buffalo, coconut and soy milk. Pharm Innovation J 6: 809- 814

Kumbhar SB, Ghosh JS, Samudre SP (2009) Microbiological analysis of pathogenic organisms in indigenous fermented milk products. Advance J Food Sci Technol 1:35-38

Londhe GK, Pal D, Raju PN (2012) Effect of packaging techniques on shelf life of brown peda, a milk-based confection. LWT- Food Sci Technol 47:117-125

NDDB (2017) National Dairy Development Board, Gujrat, India. http,// www.nddb.org/information/stats/milkprodindia

Saha N, Bhattacharjee S, Bhattacharyya S (2018) Preparation and pharmacognostic evaluation of sandesh, an Indian sweet dairy product, using natural colorant from Clitoria ternatea (Aparajita) flower. Int J Food Sci Nutr 3: 19-24

Sandhya (2010) Modified atmosphere packaging of fresh produce: current status and future needs. LWT- Food Sci Technol 43:381-392

Smith JP, Ooraikul B, Koersen WJ, Jackson ED, Lawrence RA (1986) Novel approach to oxygen control in modified atmosphere packaging of bakery products. Food Microbiol 3: 315-320

Snedecor GW, Cochran WG (1989) Statistical methods, 8th edn. IowaState University Press, Ames

Thippeswamy L, Venkateshaiah BV, Patil SB (2011) Effect of modified atmospheric packaging on the shelf stability of paneer prepared by adapting hurdle technology. J Food Sci Technol 48: 230-235 